

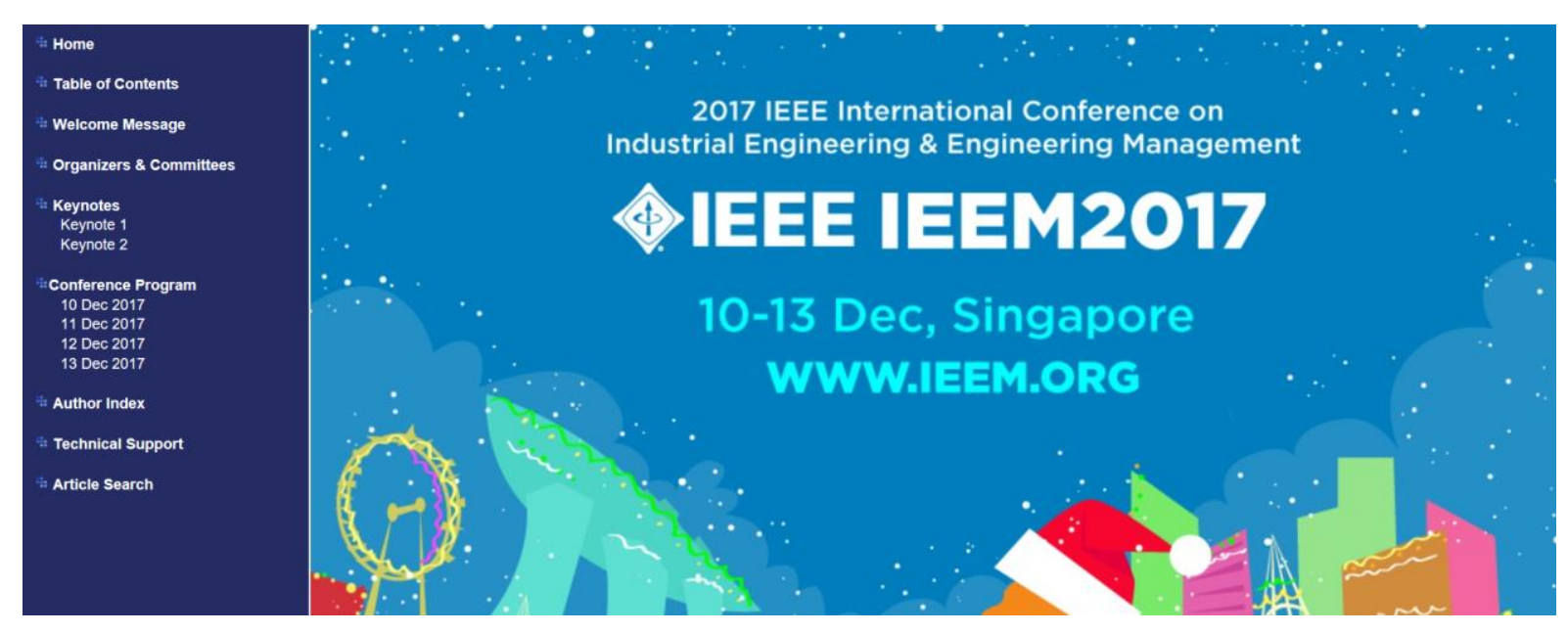

\begin{tabular}{|c|c|c|}
\hline $\begin{array}{l}\text { : Home } \\
\text { Table of Contents }\end{array}$ & \multicolumn{2}{|c|}{$\begin{array}{l}\text { Proceedings of the } 2017 \text { IEEE } \\
\text { International Conference on Industrial Engineering and Engineering Management }\end{array}$} \\
\hline : Organizers \& Committees & Editors: & Contents \\
\hline $\begin{array}{l}\text { Keynotes } \\
\text { Keynote } 1 \\
\text { Keynote } 2\end{array}$ & $\begin{array}{l}\text { Arnoud DE MEYER, General Chair } \\
\text { Singapore Management University, Singapore } \\
\text { Kah Hin CHAI, Organizing Chair } \\
\text { National University of Singapore, Singapore }\end{array}$ & $\begin{array}{l}\text { ": Welcome Message } \\
\text { ": Organizers and Committees } \\
\text { ": Keynotes }\end{array}$ \\
\hline $\begin{array}{l}\text { Conference Program } \\
10 \text { Dec } 2017 \\
11 D e c 017\end{array}$ & $\begin{array}{l}\text { Roger JIAO, Organizing Chair } \\
\text { Georgia Institute of Technology, USA }\end{array}$ & $\begin{array}{l}\text { - Keynote } 1 \text { - Rethinking Operations Strategy in an Age of Digital Manufacturing } \\
\text { - Keynote } 2 \text { - Using Kernels to Harness the Complexity of Big Data }\end{array}$ \\
\hline $\begin{array}{l}11 \text { Dec } 2017 \\
12 \text { Dec } 2017 \\
13 \text { Dec } 2017\end{array}$ & $\begin{array}{l}\text { Nan CHEN, Program Chair } \\
\text { National University of Singapore, Singapore }\end{array}$ & ": Conference Program \\
\hline : Author Index & $\begin{array}{l}\text { Min XIE, Program Chair } \\
\text { City University of Hong Kong, Hong Kong SAR }\end{array}$ & $\begin{array}{l}: 10 \text { Dec } 2017 \text { (Sun) } \\
: 11 \text { Dec } 2017 \text { (Mon) } \\
: 12 \text { Dec } 2017 \text { (Tue) } \\
: 13 \text { Dec } 2017 \text { (Wed) }\end{array}$ \\
\hline t: Technical Support & $\begin{array}{l}\text { IEEE Catalog Number: CFP17IEI-USB } \\
\text { ISBN: } 978-1-5386-0947-7 \\
\text { Technical Support: }\end{array}$ & $\begin{array}{l}\text { : Author Index } \\
\quad \text { : A-F } \\
\quad: G-L \\
\quad M-P\end{array}$ \\
\hline
\end{tabular}

Home
ta Table of Contents
Welcome Message
Organizers \& Committees
Keynotes
Keynote 1
Keynote 2
Conference Program
10 Dec 2017
11 Dec 2017
12 Dec 2017
13 Dec 2017
Author Index
at Technical Support
Article Search

"7) Dally Program: 11 Dec 112 Dec

Human Factors 3
$0900-10.45 J$ Juesday. 12 December 2017. IMR329

*2 The Extended Framework of Kansei Engineering, Kano and TRIZ Applied to Logistics Services

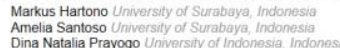
Amelia Santoso Unversity of Surabaya, Indionesia
Dina Natalia Prayogo Unversity of Indonosia, Indanesia
Ivon Universty of Surabaya, Indonesia

-7 A Low-Cost Portable 3D Human Motion Analysis System: An Application of Gait Analysis

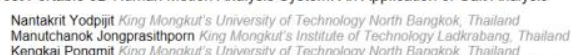

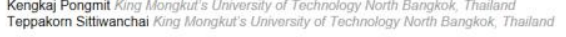

*2 Information Security in Communication Network of Memory Channel Considering Information Importance Takaaki Kawanaka The University of Tokvo, Japan
Shuichi Rokugawa The Unversity of Tokyy, Japan
Hiroshi Yamashita Mein University, Japan

The Importance of Compliance with the Expectations of the Value of Stakeholder in Order to Achieve Success in the Implementation of Lean Projects

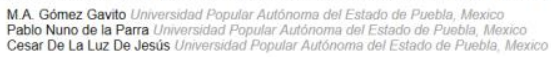




\title{
The Extended Framework of Kansei Engineering, Kano and TRIZ Applied to Logistics Services
}

\author{
Markus Hartono ${ }^{1}$, Amelia Santoso ${ }^{1}$, Dina Natalia Prayogo ${ }^{1}$, Ivon ${ }^{1}$ \\ ${ }^{1}$ Department of Industrial Engineering, University of Surabaya, Surabaya, Indonesia \\ (markus@staff.ubaya.ac.id)
}

\begin{abstract}
As one of the most rapidly growing service sectors in today's business, providing excellent quality in logistics services is a must. In services, recent research shows that affect/emotion (known as Kansei) and Kano's attractive performance are deemed to be sensitive in dealing with total satisfaction, rather than usability and functionality. However, the ideas for service improvement are often contradictory. Hence, this study proposes an integrated model of Kansei Engineering and Kano incorporating TRIZ (Teoriya Resheniya Izobretatelskikh Zadach) which contributes to the improvement of logistics services. A case study in IT-based logistics services has been conducted. The service attribute 'cleanliness of helmet for customer' has been regarded as the most critical, which dealt with Kansei professional, innovative, cheap, and precise. In addition, the modularity-based helmet cover and inner sponge has been proposed for TRIZ-based improvement.
\end{abstract}

Keywords - Kansei Engineering, Kano, TRIZ, logistics services

\section{INTRODUCTION}

In both product and service design and development, understanding customer need and want is a significant key to a distinctive quality production. Apart from tangible products, services are extensively offered in today's economy business. Not only pure intangible form, services are sometimes offered and accompanied by physical products. According to Parasuraman's SERVQUAL model [1], service attributes are divided into 2 main dimensions, namely, (i) tangible, and (ii) intangible (e.g., responsiveness, reliability, assurance and empathy).

A product or service which is designed and developed by exploring the deepest latent customer needs can fulfill the inner feeling and impression. Inherently, it is very attractive [2]. Latent customer needs are referred to the unspoken needs. These may be referred to specific problems or something the customer concerns, but have not yet realized. Once, these needs have been fulfilled by service or product designer/manager, the results will be surprising. Referring to Kano categorization, these may be related to attractive performance (or known as delighter) $[3 ; 4]$. It is something which is not verbally and expressively requested by customer. However, once it is fulfilled, they will be delighted. In addition, this particular type of need may result in significant emotional feelings (or known as Kansei) [3]. Hence, to identify, explore and satisfy the unspoken needs of customer is of big challenge in today's service research, design and development.
Affect (known as emotion or Kansei) tends to be more dominant than cognition at the final transaction [5]. It is called total customer satisfaction. Kansei Engineering (KE) has shown its superiority in capturing customer emotional needs and translating them into product/service characteristics [6;7]. Its application in services is relatively new, thus, this niche is highly relevant for research and development in obtaining service excellence.

In fulfilling the customer emotional needs, a service provider should focus on the high performance of service offerings. However, in some cases, the service performance and customer impression are not necessarily linearly correlated $[8 ; 3 ; 9]$. Fortunately, Kano's categories especially those with attractive and onedimensional ( $\mathrm{A}$ and $\mathrm{O}$ ) have potential to fill in this gap [see 9;8].

When it comes to the exploration of ideas for improvement, brainstorming is often used. Another service quality tool such as quality function deployment (QFD) is also popular. However, these tools may potentially lead to inefficiency and ineffectiveness. This is caused by the way of exploring ideas which is based more on similar past experience, existing ideas and inspiration [10].

In solving the potential problem of limited ideas for improvement, TRIZ method (literally, also known as theory of the resolution of invention-related task) has been proposed [10]. Its superiority is that to generate and provide breakthrough ideas for any service industries with less or without contradiction. However, the application of TRIZ in services is relatively rare. Moreover, potentially, this method can be extended in modeling the whole customer experience in services [8].

With regard to a holistic and comprehensive customer service experience, hence, this study is conducted to introduce an integrated framework of Kansei Engineering (KE), Kano and TRIZ in logistics services. KE focuses on emotional needs/affect which is of critical to the final decision in service encounters. Kano will strengthen the identification and categorization of service performance based on customer feedback. Kano's attractive/delighter [A] category will be of critical to Kansei. Afterwards, TRIZ will exclude any potential contradiction among ideas for improvement and lead to more innovative yet efficient improvement strategies. It is deemed to be the innovative and efficient approach in dealing with the most sensitive customer need.

In this current study, logistics services has been selected as it is one of the most growing businesses in today's economy due to the emergence of internet and information technology [10]. More specifically, third- 
party logistics (3PL) company has been chosen. Literally, it is a provider of outsourced logistics services, supported by the internet and information technology.

Hence, practically, this study is expected to provide beneficial information and guidelines or even checkpoints for service provider regarding how to improve service attributes which are critical to customer emotions (Kansei) with less contradictions.

\section{KANSEI ENGINEERING, KANO AND TRIZ}

It is a challenge for product or service designer to create offerings by taking into account the latent needs of customers. They may be referred to the unspoken needs in which Kano has categorized them into attractive need, known as delighter [4]. Customer delight moves beyond customer satisfaction and usability requirements. It is, instead, more on emotional feelings or affect. In Japanese, emotional feelings or affect is known as Kansei [11].

A powerful ergonomics-based method for product design and development incorporating emotions (or Kansei) is proposed by Nagamachi [6], well known as Kansei Engineering (KE). This method has been applied as well in services, known as Kansei quality management [11], and has been extensively tested into several service settings [3;5]. Due to rapid growth of service industry in today's economy and more complex customer expectation, the exploration of KE potential is highly interesting. It is covering not only its application into different service settings, but also its ability to integrate into relevant service quality tools. This is supported by one of the KE superiority sets [see 12].

In KE methodology, Kansei is a function of perceived service attribute performance, as a result of service experience and interaction. In other words, service attribute performance is deemed to be the stimulus to Kansei. Service attribute which is significant to a certain Kansei, should be of priority for improvement. It is an initiative should be taken by service provider or manager in promoting more efficient cost of continuous improvement [3].

Once something is provided in meeting and satisfying what the customer needs, it will lead to customer satisfaction. However, once it is fulfilled beyond what is needed and wanted, it will drive customer delight. Surely, it is significantly creating positive emotions. As a result, customer loyalty will be potentially expected. This condition is known as Kano's attractive performance, or delighter. It is something which is not verbally asked by the customers, however, a little fulfillment will bring significant satisfaction level [2]. The attractive Kano's category [A] is deemed to be an antecedent of Kansei [7]. Apart from attractive category, Kano model has two more main categories, namely, (i) basic/must-be category [M], and (ii) one-dimensional category [O]. Must-be [M] refers to what has been taken for granted by the customer; onedimensional [O] shows a linear relationship between the level of fulfillment and satisfaction. This study focuses on both attractive and one-dimensional categories which drive customer emotional satisfaction.

Service attributes which are sensitive and critical to customer Kansei need to be continuously improved. It is a stage of discovering and exploring ideas for service improvement. Most often done, generating ideas depend on designer background and past experience. It is where new and breakthrough ideas are difficult to execute. According to Chai et al. [10], the conventional service quality tools have limitation to overcome any potential cognitive biases. As a result, the solutions offered are quite normative.

In generating more innovative yet free-contradictory solutions, TRIZ (known as theory of innovative problem solving) has been promoted. This patent-based set of solutions for service design and development has been introduced by Chai et al. [10] which contains 40 inventive principles. The superiority of TRIZ-based solutions for services is that a formulation of non-contradictory among all generated particular innovative ideas.

\section{PROPOSED MODEL AND METHODOLOGY}

The proposed extended framework of Kansei Engineering, Kano and TRIZ applied in logistics services is shown in Figure 1 below. This proposed model has been constructed by adopting and modifying the one proposed by Hartono \& Tan [3] and Hartono [8]. By integrating such relevant tools, instead of using individual tools (e.g., Kansei Engineering, Kano model, and TRIZ), this proposed framework shows its superiority, i.e., it is able to capture more holistic and comprehensive customer experience in logistics services, especially the experience that leads to Kansei. It is then strengthen by Kano for identifying which service attribute is sensitive to customer delight, and followed by the proposed TRIZ-based improvement strategy.

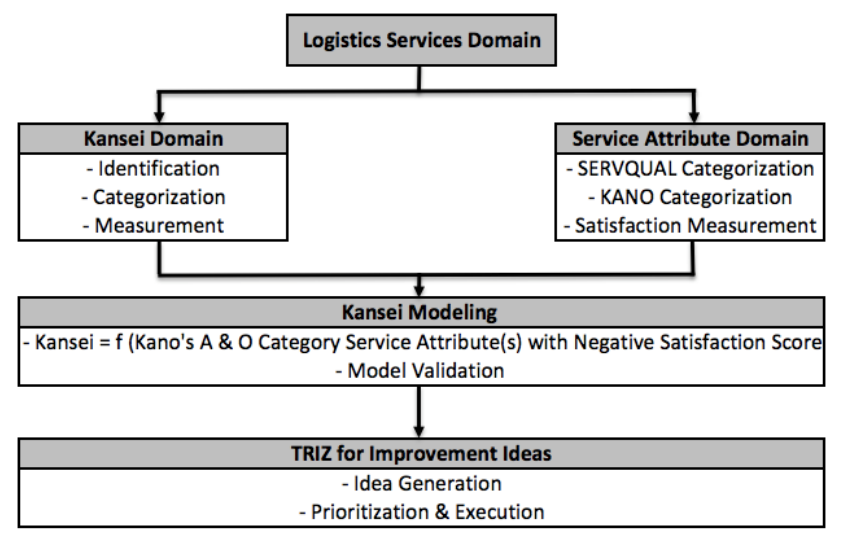

Fig. 1. The extended framework of Kansei Engineering, Kano and TRIZ applied to logistics services

It starts with the identification of Kansei words as the representation of emotional needs, and logistics services attributes. According to Hartono \& Tan [3] and Hartono [8], the measurement of perceived Kansei and service 
attributes performance will be done. A general SERVQUAL model [1] with modification which consists of 5 dimensions, namely, tangibles, responsiveness, reliability, empathy and assurance is used. Kano model is inserted to filter only attractive and one-dimensional categories (A \& O category). Afterwards, critical logistics service attributes which are those of low satisfaction score (considering the gap between perception, expectation and importance level) with Kano A \& O category will be proceeded to Kansei model. The final stage will be ideas generation for improvement using TRIZ. Similar to house of quality (HoQ) form, it will be defined what the critical logistics service attributes are, and how to improve them using contradiction and ideal solution analysis as specified by TRIZ methodology.

Purposive sampling through survey by face-to-face questionnaire is utilized. This sampling plan is appropriate when the researcher needs to reach a targeted sample quickly with non-probability concern. The researcher sets out to decide the subjects who are willing to provide particular information needed based on their experience [13].

\section{CASE STUDY AND DISCUSSION}

To test the applicability of the proposed model, an ITbased application supporting logistics services, named as $\mathrm{ABC}$, has been selected as a case study. It is a $3 \mathrm{PL}$ company equipped with pick and pack, tracking and tracing ability, and focusing on both passenger and goods delivery services. More specifically, it is well known as a hyper-local transport, logistics and payments startup. In exploring the customer need and perception, there were 200 subjects involved [ $53 \%$ female and $47 \%$ male, mostly at the age range of $16-25$ years $(55 \%)$, and professionals $(40 \%)]$.

There were 26 logistics service attributes with significant service gap reported (at significant value of 0.05), as shown in Table I. Regarding the customer emotional needs, through an affinity diagram, there were 10 Kansei words identified and validated. They include helped, trusted, secured, comfortable, innovative, friendly, precise, professional, prompt, and cheap. Kansei "helped" has been rated as the highest perceived emotion.

Afterwards, logistics service attributes with Kano's A \& O category have been linked to Kansei. It was to identify what service attributes were affecting significantly to particular Kansei. Then, it was reversed, to identify which logistics service attribute was the most sensitive. By taking into account the weighing score for each parameter in the Kansei model, the total weight for each significant logistics service attribute has been calculated. Kano weight was adopted from Tan \& Pawitra [9]. It was to decide the most critical logistics service attribute to be put as the first priority for improvement. The detailed result of this process is provided in Table II.
TABLE I

THE LOGISTICS SERVICE ATTRIBUTES SIGNIFANT GAP

\begin{tabular}{|c|c|c|}
\hline Code & Logistics service attributes & Gap* \\
\hline \multicolumn{3}{|c|}{$\begin{array}{c}\text { Tangible } \\
\end{array}$} \\
\hline $\mathrm{T}_{1}$ & Vehicle type & -0.57 \\
\hline $\mathrm{T}_{2}$ & Cleanliness of vehicle & -0.89 \\
\hline $\mathrm{T}_{3}$ & Driver performance & -0.61 \\
\hline $\mathrm{T}_{4}$ & Completeness of driver's attributes & -0.76 \\
\hline $\mathrm{T}_{5}$ & Driver rating score & -0.38 \\
\hline $\mathrm{T}_{6}$ & Web-based application interface & -0.38 \\
\hline $\mathbf{T}_{7}$ & Cleanliness of helmet for customer & -1.25 \\
\hline.$T_{8}$ & Provision of mask & -0.62 \\
\hline $\mathrm{T}_{9}$ & Food receipt & -0.64 \\
\hline $\mathrm{T}_{10}$ & Appearance of foods ordered & -0.89 \\
\hline \multicolumn{3}{|c|}{ Empathy } \\
\hline $\mathrm{E}_{11}$ & Provision of apology once any mistakes & -0.72 \\
\hline $\mathrm{E}_{12}$ & Confirmation for any unavailability of orders & -0.48 \\
\hline $\mathrm{E}_{13}$ & Confirmation for any cancellations & -0.85 \\
\hline \multicolumn{3}{|c|}{ Responsiveness } \\
\hline $\mathrm{RE}_{14}$ & Friendliness of driver & -0.68 \\
\hline $\mathrm{RE}_{15}$ & Politeness of driver & -0.81 \\
\hline $\mathrm{RE}_{16}$ & Promptness of delivery & -1.05 \\
\hline $\mathrm{RE}_{17}$ & Confirmation for any orders made & -0.53 \\
\hline $\mathrm{RE}_{18}$ & Knowledge of driver for any interesting places & -0.87 \\
\hline \multicolumn{3}{|c|}{ Reliability } \\
\hline $\mathrm{RL}_{19}$ & Accuracy of payment & -0.85 \\
\hline $\mathrm{RL}_{20}$ & Accuracy of driver identity & -0.77 \\
\hline $\mathrm{RL}_{21}$ & Accuracy of promotions & -0.51 \\
\hline $\mathrm{RL}_{22}$ & Accuracy of orders & -0.68 \\
\hline $\mathrm{RL}_{23}$ & Safety & -0.65 \\
\hline \multicolumn{3}{|c|}{ Assurance } \\
\hline $\mathrm{A} 24$ & Driver traceability & -0.56 \\
\hline $\mathrm{A} 25$ & Warranty for orders & -0.62 \\
\hline $\mathrm{A} 27$ & Privacy for customer & -0.73 \\
\hline
\end{tabular}

TABLE II

TOTAL WEIGHT OF SERVICE ATtRIBUTES

\begin{tabular}{|c|c|c|c|c|c|c|}
\hline \multirow{2}{*}{$\begin{array}{c}\text { Code } \\
\mathrm{T}_{7}\end{array}$} & \multirow{2}{*}{$\begin{array}{c}\mid \text { Satisfaction|* } \\
5.65\end{array}$} & \multicolumn{2}{|c|}{ Kano weight } & \multicolumn{2}{|c|}{ Kansei score } & \multirow{2}{*}{$\begin{array}{c}\text { Total weight* } \\
157.3\end{array}$} \\
\hline & & $\mathrm{O}$ & 2 & $\begin{array}{c}\text { Professional } \\
\text { Innovative } \\
\text { Cheap } \\
\text { Precise }\end{array}$ & $\begin{array}{l}3.41 \\
3.70 \\
3.31 \\
3.50\end{array}$ & \\
\hline $\mathrm{R}_{16}$ & 4.71 & A & 4 & $\begin{array}{c}\text { Friendly } \\
\text { Prompt } \\
\text { Trusted }\end{array}$ & $\begin{array}{l}3.60 \\
3.41 \\
3.95\end{array}$ & 132.19 \\
\hline $\mathrm{A}_{25}$ & 2.54 & A & 4 & $\begin{array}{l}\text { Secured } \\
\text { Comfortable } \\
\text { Friendly }\end{array}$ & $\begin{array}{l}3.89 \\
3.79 \\
3.60\end{array}$ & 118.25 \\
\hline $\mathrm{T}_{6}$ & 1.52 & A & 4 & $\begin{array}{c}\text { Innovative } \\
\text { Helped }\end{array}$ & $\begin{array}{l}3.71 \\
4.21\end{array}$ & 70.22 \\
\hline $\mathrm{T}_{10}$ & 3.80 & A & 4 & Helped & 4.21 & 64 \\
\hline$E_{13}$ & 3.64 & $\mathrm{O}$ & 2 & $\begin{array}{c}\text { Helped } \\
\text { Comfortable }\end{array}$ & $\begin{array}{l}4.21 \\
3.79\end{array}$ & 58.34 \\
\hline $\begin{array}{c}\mathrm{T}_{2} \\
\mathrm{R}_{18}\end{array}$ & $\begin{array}{l}3.59 \\
3.71\end{array}$ & $\begin{array}{l}\text { A } \\
\text { A }\end{array}$ & $\begin{array}{l}4 \\
4\end{array}$ & $\begin{array}{l}\text { Secured } \\
\text { Precise }\end{array}$ & $\begin{array}{l}3.89 \\
3.50\end{array}$ & $\begin{array}{l}55.81 \\
52.01\end{array}$ \\
\hline$E_{11}$ & 3.09 & A & 4 & Comfortable & 3.79 & 46.83 \\
\hline $\mathrm{R}_{15}$ & 3.64 & $\mathrm{O}$ & 2 & Trusted & 3.95 & 28.80 \\
\hline $\mathrm{A}_{24}$ & 2.38 & $\mathrm{O}$ & 2 & Helped & 4.21 & 20.04 \\
\hline $\mathrm{R}_{14}$ & 3.05 & $\mathrm{O}$ & 2 & - & & 6.11 \\
\hline
\end{tabular}

* $\mid$ satisfaction score $\mid=($ perceived - expected score $) x$ importance level

** total weight $=\mid$ satisfaction score $\mid x$ Kano weight $x$ number of Kansei $x$ average Kansei score

The grey background signifies the most critical logistics service attribute

Referring to Tables I \& II, the logistics service attribute $\mathrm{T}_{7}$ "Cleanliness of helmet for customer" has been deemed to be the most critical and sensitive to customer emotion/Kansei. Apart from attractive category, this service attribute had significant impact on four Kansei words. The problem was that most customers insisted a clean helmet for every ride. However, the helmet offered was relatively dirty and smelly. It has been caused by the helmet was not well stored, maintained and there was no special slot for storing it. 
Through TRIZ methodology, there were two main stages done, i.e., (i) problem definition. The ideal final result is expected, which was to satisfy the customer by providing more comfortable and clean helmet; and (ii) problem resolution. It was to find appropriate solutions given any possible potential contradictions, as they are provided in a contradiction matrix. Here is the formulation of improvement ideas based on potential contradiction [10], shown in Table III.

TABLE III

DESCRIPTION OF IMPROVEMENT IDEAS CONSIDERING POSSIBLE CONTRADICTION

\begin{tabular}{|c|c|}
\hline Contradiction & Description of principles for improvement* \\
\hline \multirow[t]{2}{*}{$\begin{array}{l}\text { Convenience of use } \\
\text { vs force }\end{array}$} & $\begin{array}{l}\text { - Replacement of mechanical system } \\
\text { a. To replace a mechanical system with a sensory } \\
\text { (optical, acoustical, or thermal). } \\
\text { Idea: repainting the helmet. However it is not well } \\
\text { recommended since it needs extra time, effort and } \\
\text { cost. } \\
\text { b. To replace fields that are fixed with changing in } \\
\text { time. } \\
\text { Idea: modularity-based helmet cover and inner } \\
\text { sponge. Each driver brings along } 1 \text { extra unit of } \\
\text { this feature. This is considered feasible since it is } \\
\text { easy to clean, less cost, and less effort. } \\
\text { - Do it in reverse } \\
\text { a. Instead of the direct action dictated by a problem, } \\
\text { implement an opposite action. } \\
\text { Idea: the driver asks directly the customer } \\
\text { whether any inconvenience of helmet. This is } \\
\text { considered feasible since it is a proactive idea and } \\
\text { easy to understand what makes customer convenient } \\
\text { directly. }\end{array}$ \\
\hline & $\begin{array}{l}\text { - Transformation of properties } \\
\text { a. To change the degree of flexibility } \\
\text { Idea: the ease of cleansing the helmet cover and } \\
\text { inner sponge without any specific requirement. } \\
\text { This is feasible due to less possibility of damage, } \\
\text { ease of cleansing. }\end{array}$ \\
\hline \multirow[t]{2}{*}{$\begin{array}{l}\text { Convenience of use } \\
\text { vs harmful factors } \\
\text { acting on an object } \\
\text { from outside }\end{array}$} & $\begin{array}{l}\text { Extraction } \\
\text { a. To extract only the necessary part of property from } \\
\text { an object } \\
\text { Idea: the driver asks first to the customer whether } \\
\text { hair mask is needed before riding. This is considered } \\
\text { feasible due to its efficiency. }\end{array}$ \\
\hline & $\begin{array}{l}\text { - Self service } \\
\text { a. An object must service itself and carry-out } \\
\text { supplementary and repair operations } \\
\text { Idea: it is allowed when the customer brings along } \\
\text { his own helmet and gets discount. This is considered } \\
\text { feasible. } \\
\text { b. To make use of waste material and energy } \\
\text { Idea: helmet can be cleaned by the available } \\
\text { employee who is standby at the company office. It } \\
\text { may be feasible. } \\
\text { c. To replace a normal environment with an inert one } \\
\text { Idea: helmet is stored in a special bag which is } \\
\text { waterproof, heatproof, and easy to carry. This is } \\
\text { considered feasible due to its hygiene and ease of } \\
\text { carry. }\end{array}$ \\
\hline $\begin{array}{l}\text { Reliability vs } \\
\text { productivity }\end{array}$ & $\begin{array}{l}\text { - Segmentation } \\
\text { a. To make an object easy to disassemble } \\
\text { Idea: modularity-based helmet cover and inner } \\
\text { sponge. Each driver brings along } 1 \text { extra unit of } \\
\text { this feature. This is considered feasible since it is } \\
\text { easy to clean, less cost, and less effort. } \\
\text { b. To increase the degree of fragmentation or } \\
\text { segmentation } \\
\text { Idea: a reminder through apps to clean the helmet } \\
\text { once it is already used } 10 \text { times. This is considered } \\
\text { feasible. }\end{array}$ \\
\hline & $\begin{array}{l}\text { - Pneumatic or hydraulic constructions } \\
\text { a. To replace solid parts of an object with a gas or }\end{array}$ \\
\hline
\end{tabular}

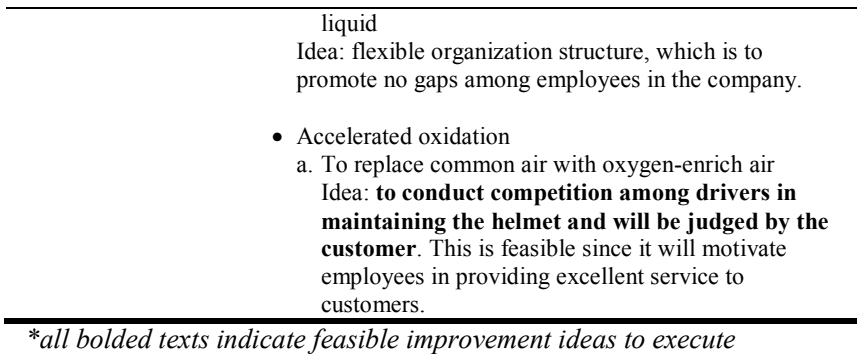

*all bolded texts indicate feasible improvement ideas to execute

With respect to company readiness in terms of cost, time and effort, some potential improvement ideas should be evaluated further and selected. In this study, modularitybased helmet cover and inner sponge may be of interest to execute.

The result of this case study has shown that the proposed framework has been successfully applied and validated. Through a short discussion with two actual customers, the selected proposed solution 'modularitybased helmet cover and inner sponge' has been regarded as sufficient yet innovative way to increase comfort for customers.

\section{CONCLUSION \& FURTHER RESEARCH}

Due to more demanding customers and tight competition in logistics services, service provider should move beyond conventional approaches. Quality, cost and delivery are regarded as basic performance to fulfill. This study proposes an extended framework of Kansei Engineering, Kano and TRIZ applied to logistics services, as a new approach in capturing the latent emotional needs (known as Kansei) and providing free-contradiction improvement ideas. It is considered as a distinctive method to understand the customers better.

Practically, this research promotes a guideline to support service manager and provider in identifying which logistics service attributes are sensitive and attractive to customer Kansei, and how to improve them efficiently and effectively.

Essentially, this study is the continuation of previous studies on Kansei Engineering applied in services, considering potential refinement of the previous methods and different service settings. This research is also of limited by a small size and narrow service scope. More empirical studies on other service settings are required.

\section{ACKNOWLEDGMENT}

This study has been fully funded and supported by the Ministry of Research, Technology and Higher Education through the research grant Applied Product with a contract number of 22/SP-Lit/LPPM-01/Dikti/FT/V/2017, and also the Department of Industrial Engineering, University of Surabaya, Indonesia. In addition, the authors thank to the Support Program of Overseas Conference by Directorate General of Strengthening for Research and Development, Ministry of Research, 
Technology and Higher Education, Republic of Indonesia (BSLN, Ditjen Penguatan Riset \& Pengembangan, Kemenristekdikti).

\section{REFERENCES}

[1] A. Parasuraman, L.L. Berry and V.A. Zeithaml, "SERVQUAL: a multiple-item scale for measuring consumer perceptions of service quality", Journal of Retailing, Vol. 64 (1988), pp. 12-40.

[2] N. Kano, N. Seraku and F. Takahashi, "Attractive quality and must be quality”, Quality, Vol. 14 (1984), No. 2, pp. $39-44$.

[3] M. Hartono and K.C. Tan, "How Kano model contributes to Kansei engineering in services", Ergonomics, Vol. 54, No. 11 (2011), pp. 987-1004.

[4] C.-C. Yang, "Identification of customer delight for quality attributes and its applications", Total Quality Management \& Business Excellence, Vol. 22, No. 1 (2011), pp. 83-98.

[5] M. Hartono and H. Raharjo, "Exploring the mediating role of affective and cognitive satisfaction on the effect of service quality on loyalty", Total Quality Management \& Business Excellence, Vol. 26 (2015), No. 9-10, pp 971 985.

[6] M. Nagamachi, "Kansei Engineering: a new ergonomic consumer-oriented technology for product development", International Journal of Industrial Ergonomics, Vol.15 (1995), pp. 3-11.

[7] M. Hartono, K.C. Tan and J.B. Peacock, "Applying Kansei Engineering, the Kano model and QFD to services", International Journal of Services, Economics and Management, Vol. 5, No. 3, pp. 256-274 (2013).

[8] M. Hartono, "The extended integrated model of Kansei Engineering, Kano, and TRIZ incorporating cultural differences into services", International Journal of Technology, Vol. 7 (2016), No. 1, pp. 97 - 104.

[9] K.C. Tan and A.T. Pawitra, "Integrating SERVQUAL and Kano's model into QFD for service excellent development", Managing Service Quality, Vol. 11 (2001), pp. 418-430.

[10] K.H. Chai, Z. Jun, and K.C. Tan, "A TRIZ-based Method for New Service Design", Journal of Service Research, Vol. 8, No. 1 (2005), pp. 48-66.

[11] M. Nagamachi and A.M. Lokman, "Innovations of Kansei engineering”, Boca Raton: CRC Press (2011).

[12] M. Hartono, "Incorporating service quality tools into Kansei Engineering in services: a case study of Indonesian tourists", Procedia Economics and Finance Vol. 4 (2012), pp. 201-212.

[13] M. D. C. Tongco, "Purposive sampling as a tool for informant selection", Ethnobotany Research \& Application, Vol. 5 (2007), pp. 147-158. 